\title{
Teachers' legitimacy: Effects of justice perception and social comparison processes
}

\author{
Maria Gouveia-Pereira ${ }^{1 *}$, Jorge Vala ${ }^{2}$ and Isabel Correia ${ }^{3}$ \\ 'CIE-ISPA, ISPA-Instituto Universitário, Lisboa, Portugal \\ ${ }^{2}$ Instituto de Ciências Sociais, Universidade de Lisboa, Lisboa, Portugal \\ ${ }^{3}$ Instituto Universitário de Lisboa (ISCTE-IUL), Centro de Investigação e Intervenção \\ Social (CIS-IUL), Lisboa, Portugal
}

Background. Teachers' legitimacy is central to school functioning. Teachers' justice, whether distributive or procedural, predicts teachers' legitimacy.

\begin{abstract}
Aims. What is still do be found, and constitutes the goal of this paper, is whether unjust treatment by a teacher affects the legitimacy of the teacher differently when the student knows that the teacher was fair to a peer (comparative judgement) or when the student does not have that information (autonomous judgement).
\end{abstract}

Samples. A total of 79 high school students participated in Study I; 75 high school students participated in Study 2.

Methods. Two experimental studies with a 2 justice valence (just, unjust) $\times 2$ social comparison processes (autonomous judgements, comparative judgements) betweenparticipants design were conducted. Study I addressed distributive justice and Study 2 addressed procedural justice. The dependent variable was teachers' legitimacy.

Results. In both studies, situations perceived as just led to higher teachers' legitimacy than situations perceived as unjust. For the distributive injustice conditions, teachers' legitimacy was equally lower for autonomous judgement and comparative judgement conditions. For procedural injustice, teachers' legitimacy was lower when the peer was treated justly and the participant was treated unfairly, compared with the condition when the participants did not know how the teacher treated the peer.

Conclusions. We conclude that teachers' injustice affects teachers' legitimacy, but it does it differently according to the social comparisons involved and the type of justice involved. Moreover, these results highlight that social comparisons are an important psychological process and, therefore, they should be taken into account in models of justice.

All teachers would like their students to co-operate with them willingly, irrespective of possible rewards or punishments. In other words, they would like to be seen as legitimate authorities. Legitimacy is 'the judgement by group members that they ought to voluntarily obey social rules and authorities, irrespective of the likelihood of reward or punishment' (Tyler, 1997: 323). When an authority is perceived as legitimate 'people place their trust in the group authorities and group rules, believing that these authorities can make the best

\footnotetext{
*Correspondence should be addressed to Maria Gouveia-Pereira, ISPA-IU, Rua Jardim do Tabaco n 34, II 49-04I Lisboa, Portugal. (e-mail: mpereira@ispa.pt).
} 
decisions about what is appropriate behaviour in a given situation' (Tyler \& Blader, 2000: 58). This is a fundamental psychological process with implications for how we function socially and politically (Jost \& Major, 2001; Tyler, 2006), in legal (Emler \& Reicher, 1987; Tyler, 1990), organizational (Greenberg, 1996; Tyler, 2011; Tyler \& Blader, 2000), intergroup relations (Costa-Lopes, Dovidio, Pereira, \& Jost, 2013), and, of course, school contexts (Gouveia-Pereira, Vala, Palmonari, \& Rubini, 2003; Yariv, 2009).

One of the main issues for research has been to understand the antecedents of the legitimacy of authorities. The justice of authorities, whether distributive (related to the fairness of the outcomes received, Adams, 1965) or procedural (related to the fairness of the procedures used in making allocation decisions, Thibaut \& Walker, 1975), has been found to predict the legitimacy of authorities (Bradford, Murphy, \& Jackson, 2014; Sprott \& Greene, 2010; van der Toorn, Tyler, \& Jost, 2011; van Dijke, De Cremer, \& Mayer, 2010), including teachers' legitimacy among college students (Tyler, 1997).

In many of these contexts, the justice judgment may, or may not, involve comparison with peers. At school, social comparison is very prevalent. However, research has not yet addressed how social comparison interacts with justice conditions to affect the legitimacy of school authorities. The goal of this paper is to investigate whether unjust treatment by a teacher affects the legitimacy of the teacher differently when the student knows that the teacher was fair to a peer (comparative judgement) or when the student does not have that information (autonomous judgement).

\section{Teachers' justice and legitimacy of authorities}

Distributive justice (or injustice) refers to the perception that the resources that are allocated to people are 'deserved' or not (Tornblom, 1992). If the reward obtained corresponds to what is expected, the situation is considered as just; if not, it is considered as unjust. The judgment of fairness may be comparative, with another person or with the same person in the past, or may be done in absolute terms (Adams, 1965). At school, grading students is a central part of the teaching process, and grades are considered a very important reward for students (Green, Johnson, Kim, \& Pope, 2007; Sabbagh \& Resh, 2016).

Procedural justice refers to the fairness of the means by which distributions, or decisions about them, are made (Thibaut \& Walker, 1975). Apart from the possibility of 'having a voice' (Thibaut \& Walker, 1975) in this process, by which the decision is reached, a fair procedure has to be based on accurate information; and the patterns and criteria for decision-making have to be consistent (across people and time). There should be a possibility of modifying and reversing decisions when new information is available, and there should be no bias in decision-making processes (Leventhal, 1980). At school, practical examples of procedural justice are being represented at meetings where decisions affecting students are made, and the same grading criteria being applied to all students (Resh \& Sabbagh, 2016).

In organizational contexts, both distributive justice and procedural justice have been found to be important for the well-being of employees and for the good functioning of organizations. However, distributive justice is more related to satisfaction with the results obtained (Alexander \& Ruderman, 1987; Kim \& Mauborgne, 1993), whereas procedural justice is more associated with the legitimacy and trust of authorities (Tyler, 2011; Tyler \& Blader, 2000; Tyler \& Degoey, 1995). Indeed, these dimensions of justice have been found 
to be independent (Sweeney \& McFarlin, 1993; Tyler \& Caine, 1981), although correlated (Greenberg, 1997; Sousa \& Vala, 2002).

At school, student perception of teachers' justice, both distributive and procedural, is related to very important positive indicators. First of all, a just teacher is better evaluated than an unjust teacher (Perkins, Guerin, \& Schleh, 1990; Tata, 1999; Tyler \& Caine, 1981). It is also related to a good adjustment to school (Chory-Assad, 2002), higher school grades (Kazemi, 2016), students' well-being (Correia \& Dalbert, 2007), less bullying towards other students (Donat, Umlauft, Dalbert, \& Kamble, 2012), and less cheating and delinquent behaviour (Donat, Dalbert, \& Kamble, 2014; Sanches, Gouveia-Pereira, \& Carugati, 2012). Some studies distinguishing between teachers' procedural and distributive justice have found that procedural justice predicted higher student motivation, more learning, and lower aggression towards the teacher (Chory-Assad, 2002). In addition, procedural justice, more than distributive justice, predicted higher liberal democratic orientation, and higher social and institutional trust (Resh \& Sabbagh, 2014).

An explanation for procedural justice having a stronger impact than distributive justice on variables related to attitudes towards authorities is given by the group-value model (Lind \& Tyler, 1988), later applied to relationships with authorities (Relational Model of Authority, Tyler \& Lind, 1992). The group-value model predicts that perceptions of legitimacy are more affected by procedural justice, than by distributive justice judgements. In fact, based on the social identity theory (Tajfel \& Turner, 1986), the group-value model (Lind \& Tyler, 1988; Tyler, Degoey, \& Smith, 1996) proposes that the relation between procedural justice and legitimacy is mediated by identity concerns, that is, the feelings of being a respected member of the group and of pride in the group as a whole.

Indeed, people need to feel they are a worthwhile and respected member of their social group (Baumeister \& Leary, 1995), and they use the way they are treated by authorities as information on their worth and on the value of their group (Tyler, 1994; Tyler \& Lind, 1992). At school specifically, fair procedures by teachers, who are ingroup authorities, make individuals feel they are respected members of their classmate peer group and that their classmate peer group is a valued group (Huo, Binning, \& Molina, 2010). In contrast, unfair procedures indicate marginality and disrespect.

In sum, according to the group-value model, the more the teacher, as an ingroup authority, is perceived as being oriented by procedural justice, that is, relational principles of neutrality, trustworthiness, and status recognition, the more he/she is perceived as legitimate (Tyler, 1989; Tyler et al., 1996).

According to this model, Gouveia-Pereira et al. (2003) conducted a correlational study, which showed that procedural justice from teachers, but not distributive justice, predicted teachers' legitimacy. Moreover, this legitimacy mediated the association between the perception of procedural justice and the students' evaluation of institutional authority (police officers, laws, and courts). Similar results were found by Emler and Reicher (2005), supporting the idea that in the school context procedural justice is more important than distributive justice.

Another set of findings showed that both procedural justice and distributive justice affect the legitimacy of authorities (Brockner \& Wiesenfeld, 1996; van der Toorn et al., 2011): the effect of procedural justice on the legitimacy of authorities is greater when outcome favourability is low (vs. high), because people are more concerned about procedural issues when they have not obtained the outcomes they desired than when they did. Similar results were found for teachers' legitimacy (Tata, 1999). 
In sum, all this empirical evidence, mostly correlational, points to the importance of both distributive justice and procedural justice of teachers for students' evaluation of teachers' legitimacy. However, although both distributive justice and procedural justice consider the importance of social comparisons for justice perceptions, we still do not know how social comparison processes, so important at school, affect teachers' legitimacy.

\section{Social comparisons in the school context}

Social comparisons are basic psychological processes in everyday life. People use comparisons as informative standards for judging themselves and others (Festinger, 1954; Guimond, 2006; Suls \& Wheeler, 2000), in particular in the context of the school, which is so important in students' self-concept building (Marsh, Kuyper, Morin, Parker, \& Seaton, 2014; Salchegger, 2016). However, research has not given much attention to the impact of social comparison processes on authority's legitimacy, which is rather surprising because very often people are aware of outcomes and procedures of authorities towards them as well as towards other people.

Furthermore, social comparison should be especially important in affecting the way justice judgements at school impact on teachers' legitimacy. Firstly, in school, teachers are constantly distributing resources (grades and punishments) according to certain procedures, and these outcomes and procedures are visible both for the student involved and for the other students, sometimes even for the whole school community. Secondly, it has been previously shown that the equity principle according to which equal outcomes should be given to equal achievements of different individuals (Deutsch, 1975), and a consistent treatment of all individuals (Leventhal, 1980) is important to determine the perception of justice for school students (Dalbert, 2004; Fan \& Chan, 1999). Thirdly, in adolescence, comparisons assume an especially important role in the construction and evaluation of the self (Baumeister, 1998; Harter, 1990, 2012).

As stated previously, distributive and procedural justice from authorities predicts legitimacy of authorities (van der Toorn et al., 2011). Two lines of research may help to explain how unjust treatment by an authority affects the legitimacy of that authority, depending on whether the participant knows about the way the authority treated a peer: research on egocentric bias on justice perception (see van Prooijen, 2008; for a review) and research on inconsistent treatment between the self and another person (van Prooijen, van den Bos, Lind, \& Wilke, 2006, Exp 2).

With regard to egocentric bias (Epley, Keysar, Van Boven, \& Gilovich, 2004; Ross \& Sicoly, 1979) on justice perceptions, it has been found that what people consider (un)just is influenced by egocentric motives. This means that justice judgements referring to the self or to other people are not the same. For distributive justice, people tend to overestimate the payment they deserve compared to what other people deserve (Messick \& Sentis, 1979). For procedural justice, a mild personal procedural injustice happening to the self is considered more unfair than a major procedural injustice happening to another target (Lind, Kray, \& Thompson, 1998; van Prooijen, 2008; for a review). Also when the negative bias is against oneself, the authority is perceived as more unfair than when the authority is negatively biased against someone else (van Prooijen et al., 2006, Study 2).

With regard to research on inconsistent treatment between the self and another person (van Prooijen et al., 2006, Study 2), when the authority is equally unfair to both the self and someone else, it is perceived as fairer compared to another condition where the authority is unjust against the self, but at the same time, fair to another person. These results highlight the importance of the social comparison processes in unjust situations, 
because the same unjust treatment is differently perceived depending on whether it is biased only against the self or is unjust both to the self and to someone else.

From these two lines of research, it can be inferred that when the teacher is unfair to a student, knowing that he was fair to a peer may make the perception of injustice even stronger. This may happen for two reasons. According to egocentric motives theorizing, people think they deserve more than others and they perceive the injustices happening to them as stronger compared to injustices happening to other people.

In addition, we can infer from the group-value model that knowing that another person was treated by an authority with fairness can communicate an even stronger marginal position in the group. Therefore, we may predict that being unjustly treated by a teacher when knowing that the teacher treated a peer with justice decreases the legitimacy of the teacher even more than when no social comparison is available.

\section{Overview of studies}

In this paper, two experimental studies were conducted aiming to determine how social comparison processes (comparative vs. autonomous judgments) and justice valence (just vs. unjust situation) affect teachers' legitimacy. Study 1 addressed distributive justice and Study 2 addressed procedural justice. In both studies, in the condition of (in)justice the authority was (un)just towards the participant: in the autonomous conditions, there was no information about the way the authority behaved towards a peer; in the social comparison condition, the participant knew that the authority was fair to a classmate peer.

For each of the studies, we make different predictions with regard to the impact of social comparison processes and justice valence on the perception of teachers' legitimacy.

For Study 1, we expect a main effect of justice valence, revealing that perceived teachers' legitimacy will be higher for just situations than for unjust situations (H1). Indeed, distributive injustice also reduces legitimacy of authorities (Tyler, 1997).

For Study 2, where procedural (in)justice is at stake, an unjust treatment from a teacher communicates a low value of the individual as a group member and consequently confers a low value to the self. Therefore, we expect teachers' legitimacy to be higher for just situations than for unjust situations (H1). Furthermore, social comparison is expected to moderate this main effect of justice valence. Therefore, when an authority is unjust to the participant, the perceived legitimacy of the authority will be even lower when there is a peer to whom the authority is just (social comparison condition), compared to a situation with no social comparison (autonomous condition). The different treatment between the self and the classmate peer, in disfavouring the self, may communicate an even lower status in the group compared to the status of other classmate peers. So, we hypothesize that in situations of injustice and comparative judgements, teachers' legitimacy will be even lower than in situations of injustice and autonomous judgements (H2).

\section{STUDY I}

\section{Method}

\section{Participants}

Seventy-nine students ( 35 males and 44 females) belonging to one of three classes (10th, 11 th, or 12th grades) in one state secondary school took part in this study. Their ages ranged between 15 and $19(M=16.85 ; S D=1.07)$. 


\section{Experimental design}

The design was between-subjects 2 justice valence (just, unjust) $\times 2$ social comparison processes (autonomous judgements, comparative judgements). Participants were randomly assigned to one of the four conditions.

\section{Variables and procedure}

Students were invited to collaborate in a study during class time. The questionnaire began with the following information 'We are doing a study about how students feel in situations of evaluation. The answers you provide will be used in this study. Imagine that you were in the following situation: The last test of one of your courses had 8 questions that had the same maximum possible score (...)'.

In the condition of justice and autonomous judgements, the participants were given the following information: 'You answered $70 \%$ of the test's questions correctly and the answers you gave were clear, complete and well written. You had a positive grade in this test'.

In the condition of justice and comparative judgements, the participants were given the following information: 'You and another student of your class answered $70 \%$ of the test questions correctly and the answers you gave were equally clear, complete and well written. Both you and the other student had a positive grade'.

In the condition of injustice and autonomous judgements, the participants were given the following information: 'You answered $70 \%$ of the test's questions correctly and the answers you gave were clear, complete and well written. You had a negative grade in this test'.

In the condition of injustice and comparative judgements, the participants were given the following information: 'You and another student of your class answered $70 \%$ of the test questions correctly and the answers you gave were equally clear, complete and well written. The other student had a positive grade and you had a negative grade'.

Afterwards, they were asked to answer the manipulation check questions and the measure of legitimation of teachers, which was the dependent variable.

To measure the legitimation of teachers, participants were asked to think about the situation that they had read and to answer to five items. These items were already used by Gouveia-Pereira et al. (2003) and are based on Tyler's (1997) three subdimensions of legitimacy 'acceptance of an authority's decisions', 'the authority's competence', and 'the evaluation of the authority'. The items were as follows: 'In general I would accept the decisions of this teacher'; 'I feel that that this teacher is pedagogically competent'; 'Overall, I would happily accept that teacher's requests'; 'That teacher would rate students accurately', in a scale from 1 (I completely disagree) to 5 (I completely agree); and finally 'How would you evaluate that teacher' in a scale from 1 (Completely unfavourable) to 5 (Completely favourable) $(\alpha=.91)$. All items loaded on one factor that explained $72.48 \%$ of the variance.

For both studies included in this paper, authorization for the administration of the questionnaire from the school boards and from the parents of the students was obtained. Students were invited to participate in a study about school life and completed the questionnaires during class time (around $15 \mathrm{~min}$ ). It was stressed that participation was anonymous and voluntary. At the end of the study, participants were debriefed and thanked for taking part. 


\section{Results and discussion}

\section{Manipulation check}

Before evaluating teachers' legitimacy, participants answered 2 items (e.g., 'The teacher graded me fairly', $\alpha=.95$ ) as manipulation check for the (in)justice manipulation regarding distributive aspects in a scale from 1 (I completely disagree) to 7 (I completely agree). ANOVA 2 justice valence (justice, injustice) $\times 2$ social comparison processes (autonomous judgements, comparative judgements) were conducted showing a main effect of justice valence, $F(1,78)=119.22, p<.001, \eta_{p}^{2}=.61$. Just situations, $M=5.27$, $S D=1.48$, were perceived as more just than the unjust situations, $M=1.96, S D=1.18$. No other effects were significant $F<1$.

\section{Hypothesis testing}

ANOVA 2 justice valence (justice, injustice) $\times 2$ social comparison processes (autonomous judgements, comparative judgements) in the measurement of legitimation of the authority of teachers showed a main effect of justice valence, $F(1,78)=59.71$, $p<.001, \eta_{p}^{2}=.44$. No other effects were significant $F<1$.

The main effect of justice valence revealed that participants in situations in which they are unjustly treated legitimated teachers less, $M=2.25, S D=0.72$, than when they are treated with justice $M=3.53, S D=0.74$.

Therefore, as predicted, we found that when distributive judgements are at stake, the legitimacy of an authority that was unjust towards the self is lower than the legitimacy of a just authority, and the fact that the target knows that the authority was just to another person does not significantly change that judgement.

The next study will investigate these effects for procedural justice.

\section{STUDY 2}

\section{Method}

\section{Participants}

Seventy-five students ( 28 males and 47 females) belonging to one of three classes (10th, 11 th, or 12th grades) in one state secondary school took part in this study. Their ages ranged between 15 and $19(M=16.91 ; S D=1.00)$.

\section{Experimental design}

The design was between-subjects 2 justice valence (just, unjust) $\times 2$ social comparison processes (autonomous judgements, comparative judgements). Participants were randomly assigned to one of four conditions.

\section{Variables and procedure}

The procedure was the same as in Study 1. The instructions changed according to the experimental conditions.

In the condition of justice and autonomous judgements, participants were given the following information: 'You had difficulties in understanding the questions and asked the teacher for help. The teacher explained your doubts. The teacher's 
explanations were clear, she took into consideration your needs and treated you with care and respect'.

In the condition of justice and comparative judgements, participants were given the following information: 'You and another student of your class had difficulties in understanding the questions and asked the teacher for help. The teacher clarified what was unclear to both you and the other student. The teacher's explanations were clear, she took into consideration your needs and treated both of you with care and respect'.

In the condition of injustice and autonomous judgements, participants were given the following information: 'You had difficulties in understanding the questions and asked the teacher for help. The teacher did not answer your doubts. The teacher's explanations were not clear, she did not take into consideration your needs and she did not treat you with respect'.

In the condition of injustice and comparative judgements, participants were given the following information: 'You and another student of your class had difficulties in understanding the questions and asked the teacher for help. The teacher clarified to the other student what was unclear. The teacher's explanations were clear, she took into consideration the other student's needs and treated him with care and respect. The teacher didn't give you any help'.

The measure of legitimation of authority of teachers was the same as in Study 1 $(\alpha=.93)$. All items loaded on one factor that explained $77.60 \%$ of the variance.

\section{Results and discussion}

\section{Manipulation check}

Before evaluating teachers' legitimacy, participants answered four items as manipulation check for the (in)justice manipulation regarding procedural aspects (e.g., 'The teacher treated me fairly', $\alpha=.97$ ) in a scale from 1 (I completely disagree) to 7 (I completely agree). ANOVA 2 justice valence (justice, injustice) $\times 2$ social comparison processes (autonomous judgements, comparative judgements) were conducted, which showed a main effect of justice valence, $F(1,74)=543.87, p<.001, \eta_{p}^{2}=.88$, a main effect of social comparison processes, $F(1,74)=5.27, p=.025, \eta_{p}^{2}=.07$, and an interaction between justice valence and social comparison processes, $F(1,74)=6.03, p=.016$, $\eta_{p}^{2}=.08$. Just situations, $M=6.18, S D=0.85$, were perceived as more just than the unjust situations, $M=1.71, S D=0.91$.

For the effect of interaction between justice valence and social comparison processes, Tukey HSD post-hoc tests $(p<.05)$ showed that when the situation is just, there are no significant differences $(\phi=.999)$ between the impact of autonomous judgements, $M=6.17, S D=0.93$, and comparative judgements, $M=6.20, S D=0.80$, in the perception of teacher's justice, whereas when the situation is unjust, the teachers are perceived as less just $(p=.006)$ for comparative judgements condition, $M=1.25$, $S D=0.43$, than for autonomous judgements condition, $M=2.16, S D=1.02$.

\section{Hypothesis testing}

ANOVA 2 justice valence (justice, injustice) $\times 2$ social comparison processes (autonomous judgements, comparative judgements) in the measurement of legitimation of the authority of teachers showed a main effect of justice valence, $F(1,74)=199.06$, $p<.001, \eta_{p}^{2}=.74$, a marginally significant effect of social comparison processes, $F(1$, 
$74)=3.34, p=.071, \eta_{p}^{2}=.05$, and a significant interaction effect between justice valence and social comparison processes, $F(1,74)=6.23, p=.015, \eta_{p}^{2}=.08$.

The main effect of justice valence revealed that participants in situations in which they are unjustly treated legitimate teachers less, $M=1.98, S D=0.65$, than when they are treated with justice, $M=3.80, S D=0.51$. The marginally significant effect of social comparison processes showed that the participants tend to legitimize teachers less when the judgements are comparative, $M=2.79, S D=1.21$, than when the judgements are autonomous, $M=2.96, S D=0.95$.

For the effect of interaction between justice valence and social comparison processes (Figure 1), Tukey HSD post-hoc tests $(\phi<.05)$ showed that when the situation is just, there are no significant differences between the impact of autonomous judgements, $M=3.76, S D=0.44$, and comparative judgements $M=3.84, S D=0.59$, in the legitimation of teachers, whereas when the situation is unjust, the legitimation of teachers is lower for comparative judgements, $M=1.69, S D=0.50$, than for autonomous judgements, $M=2.25, S D=0.68$.

As predicted and already found for distributive justice, a just teacher was considered more legitimate than an unjust teacher (H1). The just teacher was not perceived differently legitimate whether or not the participant knew that a peer had been fairly treated, but the unjust teacher was perceived less legitimate when the participant knew that a peer had been fairly treated than when the participant only had information about how the teacher treated the self $(\mathrm{H} 2)$.

\section{GENERAL DISCUSSION}

The studies presented in this paper aimed to explore the joint impact of social comparison processes in the legitimation of school authority under distributive justice and procedural (in)justice. Overall, the results confirmed our hypotheses.

The situations perceived as just lead to a higher teachers' legitimacy than the unjust situations whether the injustice is procedural/relational or distributive. These results are in line with other studies, in the school context (Tata, 1999; Tyler \& Caine, 1981) and in the organizational context (Alexander \& Ruderman, 1987; Greenberg, 1987; Sousa \& Vala, 2002; Tyler, 1997). If students are graded fairly and feel that they are justly treated, this

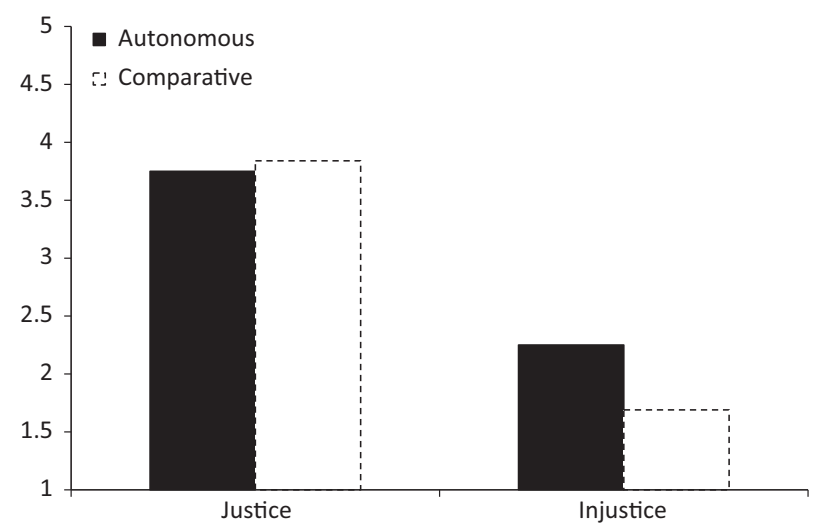

Figure I. The interaction effect between justice valence and social comparison processes on teachers' legitimacy. 
facilitates the internalization of the norm 'with just teachers it is just that one obeys', accepting the particular teachers' decisions and proposals voluntarily.

For the conditions of justice (either distributive in Study 1, or procedural in Study 2), the fact that the judgment was autonomous or comparative did not affect teachers' legitimacy.

However, a different pattern of results was obtained for the injustice conditions, depending on the type of justice involved. For distributive injustice, either an autonomous judgement or a comparative judgement resulted in lower teachers' legitimacy. For procedural injustice, the legitimation of teachers was lower when participants were treated unjustly, but it was even lower when colleagues were treated with justice and the participant was treated unfairly. Therefore, Hypothesis 2 was only supported for procedural justice in the same line with the results of van Prooijen et al. (2006, Study 2).

We conclude that teachers' injustice affects teachers' legitimacy, but it does it differently according to the social comparisons involved and the type of justice involved. When the teacher is distributively unjust towards the participant, knowing or not that a peer has been treated justly by the teacher did not change teachers' legitimacy. When the teacher is procedurally unjust towards the participant, knowing that a peer has been treated justly by the teacher decreased teachers' legitimacy even more.

When an authority is procedurally unfair regarding the individual, it threatens the worth of the individual and the value of the group to which the individual belongs (Tyler, 1994; Tyler \& Lind, 1992). The justice of the procedures, as well as the quality of treatment by an authority, has more impact on the identity process than the distributions (Lind \& Tyler, 1988).

A possible explanation for this result is that the unjust situations in which comparative judgements are salient (the individual is the target of injustice and the other person is treated with justice) are more humiliating and threatening to the self (Crosby, 1984) than when autonomous judgements are salient. As suggested by Branscombe and Wann (1994), people give more importance and return to comparative judgements more often when they feel insecure and threatened.

Therefore, our results show the importance of just procedures and the quality of treatment by teachers for the feeling of respect inside the group, promoting a greater identification between the self and the classmate peer group, and therefore, promoting the public and social identity of the adolescent.

This is an important finding that should be taken into account by the teachers. Besides being just when they grade students, it is also very important that they make an effort to treat all students with fairness, especially in a comparative set, as is almost always the case at school. Giving students fair grades, being consistent (across people and time) on the procedures employed, giving students a 'voice', and the possibility of changing decisions when new information is available are examples of ways by which teachers can be just. This just treatment can be an important preventer of indiscipline (Yariv, 2009), bullying (Donat et al., 2012), deviance (Sanches et al., 2012), exclusion, and delinquency (Emler \& Reicher, 2005).

Moreover, these results highlight that social comparisons are an important psychological process in the way justice affects legitimacy, and therefore, they should also be taken into account in justice models. Although social comparison is a fundamental process in the construction of social identity (Hogg, 2000), and the group-value model considers that justice judgements are related to identity concerns, this model has not integrated the social comparison processes. Our results are therefore a contribution to the development of the group-value model. 
Although the results are according to the predictions and the group-value model, future studies should try to replicate these results with other participants and other manipulations of justice, either distributive or procedural. These studies should also compare the effects of distributive and procedural justice on teacher legitimacy, with both being manipulated in the same study.

Furthermore, these results were done using hypothetical scenarios of a situation happening at school. Future studies with experimental manipulations with increased ecological validity, although always taking into account the respect for ethical concerns, could produce results with more external validity. Of course, we are aware that justice perception is subjective and that, in real life, the same outcomes and/or the same procedures may be differently perceived by different people, according to their personal dispositions or situational characteristics. Furthermore, students and teachers may have different perceptions of the justice of the same outcome or procedure.

Another limitation of our studies is the fact that the manipulations of distributive and procedural (in)justice are not completely 'pure': A teacher that grades students (un)justly is not always being distributively (un)just, but is also applying the procedures (in)correctly. However, we still found different results for each of the dimensions of justice. Indeed, it was repeatedly found before that, even when correlated, these two dimensions of justice predict different outcomes (Sousa \& Vala, 2002; Sweeney \& McFarlin, 1993).

A possible extension of our studies is to consider the situation where an authority is unfair, but by benefiting the self, instead of being prejudicial to the self. In this case, it is possible that the injustice will lower the authority legitimacy because people perceive the situation as unjust (Pretsch et al., 2016; van den Bos, Peters, Bobocel, \& Ybema, 2006), but the process involved will differ, because there is not a threat to the self.

Nevertheless, our studies have the advantage of integrating the joint analysis concerning the dimensions of relational and distributive justice, just and unjust situations, and autonomous and comparative judgements. This contributes to a broader understanding of the implications that justice questions have in the legitimation of school authority and how the relationship with authority can influence the definition of the self.

As we know, the significant authorities work as models of behaviour socialization to adopt, especially for adolescents. So we can infer the enormous responsibility that the school authorities take on in the social life of the individual, not only in how they are fair to each student, but also by how they differentiate their treatment among students.

\section{Acknowledgements}

This research was partially supported by a doctoral scholarship (no. 13690/97) awarded to the first author by the Portuguese Fundação para a Ciência e a Tecnologia.

\section{References}

Adams, J. S. (1965). Inequity in social exchange. In L. Berkowitz (Ed.), Advances in experimental social psychology (Vol. 2, pp. 267-299). New York, NY: Academic Press.

Alexander, S., \& Ruderman, A. (1987). The role of procedural and distributive justice in organizational behavior. Social Justice Research, 1, 177-198. doi:10.1007/BF01048015

Baumeister, R. F. (1998). The self. In D. T. Gilbert, S. T. Fiske \& G. Lindzey (Eds.), Handbook of social psychology (4th ed., pp. 680-740). New York, NY: McGraw-Hill. 
Baumeister, R. F., \& Leary, M. R. (1995). The need to belong: Desire for interpersonal attachments as a fundamental human motivation. Psychological Bulletin, 117, 497-529. doi:10.1037/00332909.117.3.497

Bradford, B., Murphy, K., \& Jackson, J. (2014). Officers as mirrors: Policing, procedural justice and the (re)production of social identity. British Journal of Criminology, 54, 527-550. doi:10.1093/ bjc/azu021

Branscombe, N. R., \& Wann, D. L. (1994). Collective self-esteem consequences of outgroup derogation when a valued social identity is on trial. European Journal of Social Psychology, 24, 641-657. doi:10.1002/ejsp.2420240603

Brockner, J., \& Wiesenfeld, B. (1996). An integrative framework for explaining reactions to decisions: Interactive effects of outcomes and procedures. Psychological Bulletin, 120, 189208. doi:10.1037/0033-2909.120.2.189

Chory-Assad, R. M. (2002). Classroom justice: Perceptions of fairness as a predictor of student motivations, learning, and aggression. Communication Quarterly, 50, 58-77. doi:10.1080/ 01463370209385646

Correia, I., \& Dalbert, C. (2007). Belief in a just world, justice concerns, and well-being at Portuguese schools. European Journal of Psychology of Education, 22, 421-437. doi:10.1007/BF0317 3464

Costa-Lopes, R., Dovidio, J. F., Pereira, C., \& Jost, J. T. (2013). Social psychological perspectives on the legitimation of social inequality: Past, present and future. European Journal of Social Psychology, 43, 229-237. doi:10.1002/ejsp.1966

Crosby, F. J. (1984). The denial of personal discrimination. American Behavioral Scientist, 27, 371386. doi: $10.1177 / 000276484027003008$

Dalbert, C. (2004). The implications and functions of just and unjust experiences in school. In C. Dalbert \& H. Sallay (Eds.), The justice motive in adolescence and young adulthood: Origins and consequences (pp. 117-134). London, UK: Routledge.

Deutsch, M. (1975). Equity, equality and need: What determines which value will be used as the basis for distributive justice? Journal of Social Issues, 31, 137-149. doi:10.1111/j.15404560.1975.tb01000.x

Donat, M., Dalbert, C., \& Kamble, S. V. (2014). Adolescents' cheating and delinquent behavior from a justice-psychological perspective: The role of teacher justice. European Journal of Psychology of Education, 29, 635-651. doi:10.1007/s10212-014-0218-5

Donat, M., Umlauft, S., Dalbert, C., \& Kamble, S. V. (2012). Belief in a just world, teacher justice, and bullying behavior. Aggressive Behavior, 38, 185-193. doi:10.1002/ab.21421

Emler, N., \& Reicher, S. (1987). Orientations to institutional authority in adolescence. Journal of Moral Education, 16, 108-116.

Emler, N., \& Reicher, S. (2005). Delinquency: Cause or consequence of social exclusion? In D. Abrams, J. Marques \& M. Hogg (Eds.), The social psychology of inclusion and exclusion (pp. 211-241). Philadelphia, PA: Psychology Press.

Epley, N., Keysar, B., Van Boven, L., \& Gilovich, T. (2004). Perspective taking as egocentric anchoring and adjustment. Journal of Personality and Social Psychology, 87, 327-339. doi:10.1037/0022-3514.87.3.327

Fan, R. M., \& Chan, S. C. N. (1999). Students' perceptions of just and unjust experiences in school. Educational and Child Psychology, 16, 32-50.

Festinger, L. (1954). A theory of social comparison processes. Human Relations, 7, 271-282. doi: $10.1177 / 001872675400700202$

Gouveia-Pereira, M., Vala, J., Palmonari, A., \& Rubini, M. (2003). School experience, relational justice and legitimation of institutional authorities. European Journal of Psychology of Education, 18, 309-325. doi:10.1007/BF03173251

Green, S. K., Johnson, R. L., Kim, D. H., \& Pope, N. S. (2007). Ethics in classroom assessment practices: Issues and attitudes. Teaching and Teacher Education, 23, 999-1011. doi:10.1016/ j.tate.2006.04.042 
Greenberg, J. (1987). Reactions to procedural injustice in payment distributions: Do the means justify the ends? Journal of Applied Psychology, 72, 55-61. doi:10.1037/0021-9010.72.1.55

Greenberg, J. (1996). The quest for justice on the job: Essays and experiments. Thousand Oaks, CA: Sage Publications Inc.

Greenberg, J. (1997). Organizational justice: Yesterday, today, and tomorrow. Journal of Management, 16, 399-432. doi:10.1177/014920639001600208

Guimond, S. (2006). Social comparison and social psychology. Understanding cognition, intergroup relations and culture. Cambridge, UK: Cambridge University Press.

Harter, S. (1990). Processes underlying adolescents' self-concept formation. In R. Montemayor, G. R. Adams \& T. P. Gullota (Eds.), From childhood to adolescence: A transitional period. Newbury Park, CA: Sage Publications.

Harter, S. (2012). The construction of the self: Developmental and sociocultural foundations (2nd ed.). New York, NY: Guilford Press.

Hogg, M. A. (2000). Social identity and social comparison. In J. Suls \& L. Wheeler (Eds.), Handbook of social comparison: Theory and research (pp. 401-421). New York, NY: Kluwer Academic/ Plenum Publishers.

Huo, Y. J., Binning, K. R., \& Molina, L. E. (2010). Testing an integrative model of respect: Implications for social engagement and well-being. Personality and Social Psychology Bulletin, 36, 200212. doi:10.1177/0146167209356787

Jost, J. T., \& Major, B. (Eds.) (2001). The psychology of legitimacy: Emerging perspectives on ideology, justice, and intergroup relations. New York, NY: Cambridge University Press.

Kazemi, A. (2016). Examining the interplay of justice perceptions, motivation, and school achievement among secondary school students. Social Justice Research, 29, 103-118. doi:10.1007/s11211-016-0261-2

Kim, W., \& Mauborgne, R. (1993). Procedural justice and subsidiary top management compliance with multinationals' corporate strategic decisions. Academy of Management Journal, 36, 502526. doi: $10.2307 / 256590$

Leventhal, G. S. (1980). What should be done with equity theory? New approaches to the study of fairness in social relationships. In K. Gergen, M. Greenberg \& R. Willis (Eds.), Social exchange: Advances in theory and research (pp. 27-55). New York, NY: Plenum Press.

Lind, E. A., Kray, L., \& Thompson, L. (1998). The social construction on injustice: Fairness judgements in response to own and others' unfair treatment by authorities. Organizational Behavior and Human Decision Processes, 75, 1-22. doi:10.1006/obhd.1998.2785

Lind, E. A., \& Tyler, T. R. (1988). The social psychology of procedural justice. New York, NY: Plenum Press.

Marsh, H. W., Kuyper, H., Morin, A. S., Parker, P. D., \& Seaton, M. (2014). Big-fish-little-pond social comparison and local dominance effects: Integrating new statistical models, methodology, design, theory and substantive implications. Learning and Instruction, 33, 50-66. doi:10.1016/ j.learninstruc.2014.04.002

Messick, D. M., \& Sentis, K. P. (1979). Fairness and preference. Journal of Experimental Social Psychology, 15, 418-434. doi:10.1016/0022-1031(79)90047-7

Perkins, D., Guerin, D., \& Schleh, J. (1990). Effects of grading standards information, assigned grade and grade discrepancies on students' evaluations. Psychological Reports, 66, 635-642. doi:10.2466/pr0.1990.66.2.635

Pretsch, J., Ehrhardt, N., Engl, L., Risch, B., Roth, J., Schumacher, S., \& Schmitt, M. (2016). Injustice in school and students' emotions, well-being, and behavior: A longitudinal study. Social Justice Research, 29, 119-138. doi:10.1007/s11211-015-0234-x

Resh, N., \& Sabbagh, C. (2014). Sense of justice in school and civic attitudes. Social Psychology of Education, 17, 51-72. doi:10.1007/s11218-013-9240-8

Resh, N., \& Sabbagh, C. (2016). Justice and education. In C. Sabbagh \& M. Schmitt (Eds.), Handbook of justice theory and research (pp. 349-368). New York, NY: Springer. 
Ross, M., \& Sicoly, F. (1979). Egocentric biases in availability and attribution.Journal of Personality and Social Psychology, 37, 322-336. doi:10.1037/0022-3514.37.3.322

Sabbagh, C., \& Resh, N. (2016). Unfolding justice research in the realm of education. Social Justice Research, 29, 1-13. doi:10.1007/s11211-016-0262-1

Salchegger, S. (2016). Selective school systems and academic self-concept: How explicit and implicit school-level tracking relate to the big-fish-little-pond effect across cultures. Journal of Educational Psychology, 108, 405-423. doi:10.1037/edu0000063

Sanches, C., Gouveia-Pereira, M., \& Carugati, F. (2012). Justice judgements, school failure, and adolescent deviant behavior. British Journal of Educational Psychology, 82, 606-621. doi:10.1111/j.2044-8279.2011.02048.x

Sousa, F., \& Vala, J. (2002). Relational justice in organizations: The Group-Value Model and support for change. Social Justice Research, 15, 99-121. doi:10.1023/A:1019967705790

Sprott, J. B., \& Greene, C. (2010). Trust and confidence in the courts does the quality of treatment young offenders receive affect their views of the courts? Crime \& Delinquency, 56, 269-289. doi: $10.1177 / 0011128707308176$

Suls, J., \& Wheeler, L. (2000). A selective history of classic social comparison theory and neo social comparison theory. In J. Suls \& L. Wheeler (Eds.), Handbook of social comparison: Theory and research (pp. 3-22). New York, NY: Kluwer Academic/Plenum Publishers.

Sweeney, P. D., \& McFarlin, D. B. (1993). Workers' evaluations of the "ends" and the "means": An examination of four models of distributive and procedural justice. Organizational Behavior and Human Decision Processes, 55, 23-40. doi:10.1006/obhd.1993.1022

Tajfel, H., \& Turner, J. (1986). The social identity theory of intergroup behavior. In S. Worchel (Ed.), Psychology of intergroup relations. Chicago, IL: Nelson Hall.

Tata, J. (1999). Grade distributions, grading procedures, and students' evaluations of instructors: A justice perspective. The Journal of Psychology, 133, 263-271. doi:10.1080/002239899095 99739

Thibaut, J., \& Walker, L. (1975). Procedural justice: Psychological analysis. Hillsdale, NJ: Lawrence Earlbaum.

Tornblom, K. Y. (1992). The social psychology of distributive justice. In K. R. Scherer (Ed.), Justice: Interdisciplinary perspectives. Cambridge, UK: Cambridge University Press.

Tyler, T. R. (1989). The psychology of procedural justice: A test of the group-value model.Journal of Personality and Social Psychology, 57, 830-838. doi:10.1037/0022-3514.57.5.830

Tyler, T. (1990). Why people obey the law. New Haven, CT: Yale University Press.

Tyler, T. (1994). Psychological models of justice motive: Antecedents of distributive and procedural justice. Journal of Personality and Social Psychology, 67, 850-863. doi:10.1037/0022-3514. 67.5 .850

Tyler, T. (1997). The psychology of legitimacy: A relational perspective on voluntary deference to authorities. Personality and Social Psychology Review, 1, 323-345. doi:10.1207/s15327957p spr0104_4

Tyler, T. R. (2006). Psychological perspectives on legitimacy and legitimation. Annual Review of Psychology, 57, 375-400. doi:10.1146/annurev.psych.57.102904.190038

Tyler, T. R. (2011). Trust and legitimacy: Policing in the USA and Europe. European Journal of Criminology, 8, 254-266. doi:10.1177/1477370811411462

Tyler, T., \& Blader, S. L. (2000). Cooperation in groups: Procedural justice, social identity and behavioural engagement. Philadelphia, PA: Psychology Press.

Tyler, T., \& Caine, A. (1981). The influence of outcomes and procedures on satisfaction with formal leaders. Journal of Personality and Social Psychology, 41, 642-655. doi:10.1037/00223514.41.4.642

Tyler, T., \& Degoey, P. (1995). Collective restraint in social dilemmas, procedural justice and social identification effects on support for authorities. Journal of Personality and Social Psychology, 69, 482-497. doi:10.1037/0022-3514.69.3.482 
Tyler, T., Degoey, P., \& Smith, H. (1996). Understanding why the justice of group procedures matters: A test of the psychological dynamics of the group-value model. Journal of Personality and Social Psychology, 70, 913-930. doi:10.1037/0022-3514.70.5.913

Tyler, T., \& Lind, E. A. (1992). A relational model of authority in groups. In. M. Zanna (Ed.), Advances in experimental social psychology (Vol. 25, pp. 115-191). New York, NY: Academic Press.

van den Bos, K., Peters, S. L., Bobocel, D. R., \& Ybema, J. F. (2006). On preferences and doing the right thing: Satisfaction with advantageous inequity when cognitive processing is limited. Journal of Experimental Social Psychology, 42, 273-289. doi:10.1016/j.jesp.2005.04.003

van der Toorn, J., Tyler, T. R., \& Jost, J. T. (2011). More than fair: Outcome dependence, system justification, and the perceived legitimacy of authority figures. Journal of Experimental Social Psychology, 47, 127-138. doi:10.1016/j.jesp.2010.09.003

van Dijke, M., De Cremer, D., \& Mayer, D. M. (2010). The role of authority power in explaining procedural fairness effects. Journal of Applied Psychology, 95, 488-502. doi:10.1037/ a0018921

van Prooijen, J.-W. (2008). Egocentrism in procedural justice effects. In K. Hegtvedt \& J. Clay-Warner (Eds.), Advances in group processes: Justice (Vol. 25, pp. 29-54). Bingley, UK: JAI press.

van Prooijen, J.-W., van den Bos, K., Lind, E. A., \& Wilke, H. A. M. (2006). How do people react to negative procedures? On the moderating role of authority's biased attitudes. Journal of Experimental Social Psychology, 42, 632-645. doi:10.1016/j.jesp.2005.11.004

Yariv, E. (2009). Students' attitudes on the boundaries of teachers' authority. School Psychology International, 30, 92-111. doi:10.1177/0143034308101852

Received 7 February 2016; revised version received 8 September 2016 